\title{
Numerical Analysis of Orthotropic Composite Propellers
}

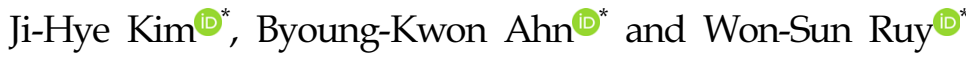 \\ *Department of Naval Architecture and Ocean Engineering, Chungnam National University, Daejon, Korea

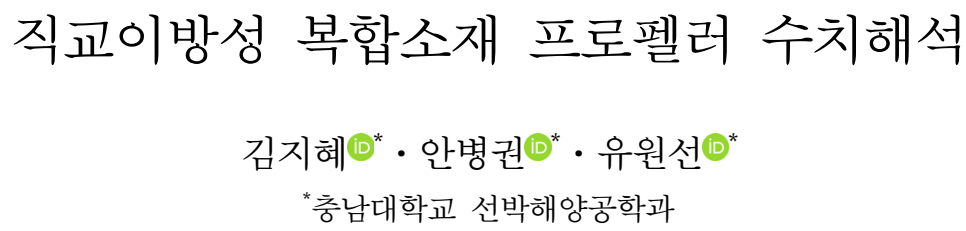

KEY WORDS: Composite propeller 복합소재 프로펠러, Carbon fiber reinforced plastic 탄소섬유강화플라스틱, Fluid-structure interaction analysis 유체-구조 연성해석 Lifting surface theory 양력면이론

\begin{abstract}
Flexible composite propellers have a relatively large deformation under heavy loading conditions. Thus, it is necessary to accurately predict the deformation of the blade through a fluid-structure interaction analysis. In this work, we present an LST-FEM method to predict the deformation of a flexible composite propeller. Here, we adopt an FEM solver called OOFEM to carry out a structural analysis with an orthotropic linear elastic composite material. In addition, we examine the influence of the lamination direction on the deformation of the flexible composite propeller.
\end{abstract}

\section{1. 서 론}

기존의 동합금보다 가볍고 성능이 우수한 CFRP(Composite fiber reinforced plastic) 소재는 자동차나 항공 산업뿐만 아니라 조선 업계에서도 고강도 경량 구조재로서 주목받고 있다. 특히, $\mathrm{CFRP}$ 소재를 적용한 유연 프로펠러는 동합금을 주재료로 사용 하는 기존의 선박용 프로펠러를 대체하여 상당한 무게 절감이 가능하며, 이로 인한 연비 저감 및 효율 향상 효과가 있다. 또 한, 캐비테이션 유기소음 및 침식 성능 향상, 피로 성능 및 진동 감쇠 특성 개선 등의 이점을 갖는 것으로 알려져 있다(Mouritz et al., 2001). 기존 선박용 프로펠러는 모든 작동 조건 하에서 변 형을 무시할 수 있는 반면, 복합소재를 적용한 유연 프로펠러의 경우 무거운 하중 조건하에서 상대적으로 큰 변형을 가진다. 이 러한 날개의 유연성으로 인해 설계자는 프로펠러의 초기 설계 단계에서 다양한 하중 조건에 따른 날개의 변형을 고려해야 하 며, 이는 프로펠러 성능이 프로펠러의 형상과 직접적으로 관련 되어 있기 때문에 매우 중요하다. 또한, 프로펠러 형상의 변화 를 고려하여 날개의 변형 이후에 설계 점에서 원하는 하중을 발생시킬 수 있도록 형상을 역설계할 필요가 있다. 이를 위해서 는 주변의 유체역학적 힘뿐만 아니라 유연 날개의 변형에 따른 구조 응답해석이 요구된다. 따라서 유체-구조의 상호작용이 고
려된 유탄성 해석 기술과 선체 후류에서 작동하는 선박용 프로 펠러의 특수한 조건을 고려하여 설계할 수 있는 기본 기술이 필요하며, 이를 고도화하여 최종적으로 복합소재 유연 프로펠 러의 최적 설계를 가능하게 하는 기술이 요구된다. 3차원 복합 소재 프로펠러에 대한 초기 수치해석 모델은 $\operatorname{Lin}(1991)$ 에 의해 제안되었다. 복합소재 프로펠러와 동일한 형상의 기존 금속재 프로펠러의 응력을 계산하여 비교하였으며, 이어 Lin and Lin (1996)은 프로펠러의 유탄성 해석법으로 프로펠러의 비선형 형 상을 고려한 3-D FEM/VLM(Finite element method/Vortex lattice method) 방법을 제시하고 정상 상태에서 복합소재 프로펠러가 받는 유탄성 거동을 계산하였다. 그 후 해당 연구팀은 복합소재 의 적층 방식에 따른 프로펠러의 거동에 대한 해석을 성공적으 로 수행한 바 있다(Lin et al., 2005). Chen et al.(2006)은 강체 및 유연 프로펠러의 설계, 수치해석 및 모형시험을 수행하였으며, 모형시험은 NSWCCD(Naval Surface Warfare Center Carderock Division)의 36인치 터널에서 실시되었다. 모형시험 결과, 유연 프로펠러의 성능이 기존 프로펠러 대비 효율 및 캐비테이션 관 점에서 우수함을 보였다. 또한 Young(2008)은 불균일 유동장 내 에서 미소 탄성 변형을 갖는 복합소재 프로펠러의 유체-구조 연 성해석을 위한 $\mathrm{BEM}$ (Boundary element method)-FEM 접근법을 제시하고 이를 통해 발생할 공동 형상과 프로펠러의 성능 및

Received 15 January 2019, revised 3 September 2019, accepted 16 October 2019

Corresponding author Byoung-Kwon Ahn: +82-42-821-6625; bkahn@cnu.ac.kr ORCID: https://orcid.org/0000-0002-0339-6069

It is noted that this paper is revised edition based on proceedings of the Annual Autumn Conference, SNAK 2018 in Changwon.

(c) 2019, The Korean Society of Ocean Engineers

This is an open access article distributed under the terms of the creative commons attribution non-commercial license (http://creativecommons.org/licenses/by-nc/3.0) which permits unrestricted non-commercial use, distribution, and reproduction in any medium, provided the original work is properly cited. 
응력 분포를 예측하였다. 이어 적층 모델을 적용하여 대변형을 갖는 복합소재 프로펠러의 유탄성 해석을 수행하고, 이를 $\mathrm{NSWCCD}$ 에서 수행한 실험과의 비교를 통해 검증하였다. 그 후 최근까지 이방성 소재의 적용에 따른 굽힘-비틀림 연동 효과와 하중에 따른 자체 변형 효과가 있는 복합소재 프로펠러의 비정 상 성능해석 및 최적 설계 기법 개발(Motley et al., 2009; Motley and Young, 2011; Motely et al., 2013)을 수행해오고 있다. Hong et al.(2012)은 복합소재 프로펠러의 구조적 감쇠 효과를 예측하는 수치해석법을 제안하였고, 이어 3차원 FEM-CFD(Computational Fluid Dynamics) 연성 해석 기법을 사용하여 다양한 복합소재 프로펠러의 유탄성 해석을 수행하였다(Hong et al., 2017). Lee et al.(2017)은 BEM-FEM 연성 해석 기법을 이용하여 적층 모델을 고려한 복합소재 프로펠러의 정상 및 비정상 성능해석을 수행 하였다.

본 연구팀은 복합소재 유연 프로펠러의 유탄성 성능 해석을 위해 VLM을 기반으로 하는 프로펠러 유동해석 프로그램인 $\mathrm{KPA} 4$ 와 프로펠러의 구조해석을 위해 Nho et al.(2004)이 개발한 프로펠러 강도 해석 프로그램인 ProSTEC을 이용하여, 이전 연 구를 통해 두 해석 프로그램의 인터페이스를 구축하고 유연 프 로펠러의 역설계 기법을 제시한 바 있다(Jang et al., 2012). 이후 불균일 반류장에서 작동하는 유연 프로펠러의 비정상 성능해석 을 수행하여 프로펠러의 변형을 예측하고, 진동과 침식을 피하 기 위한 동적 거동에 대한 수치 해석을 수행하였다(Kim et al., 2018). 그러나 이전 연구 단계에서는 프로펠러 날개를 등방성 소재에 국한하여 해석을 수행하였기 때문에 복합소재의 특성과 적층에 따른 프로펠러의 동적 거동을 예측하기에는 어려움이 있다. 결과적으로 복합소재 프로펠러의 정확한 동적 거동 해석 을 위해서는 직교이방성(Orthotropic) 혹은 보다 일반적인 이방 성(Anisotropic) 소재의 적용이 필요하며, 또한 적층된 재료의 특 성을 정확하게 반영해야 한다. 이를 위해 기존의 등방성 소재에 국한했던 구조해석 방법을 적층 복합소재의 적용이 가능한 구 조해석 방법으로 전환하고, 복합소재 및 적층 방식에 따라 균일 유동장 내에서 작동하는 복합소재 유연 프로펠러의 응력 및 변 형량을 예측하고자 하였다.

\section{2. 적층 복합소재의 구조해석}

\section{1 구조 해석법의 확장}

복합소재 프로펠러는 기존 금속재 프로펠러 대비 큰 변형량 을 가지며, 프로펠러는 스큐(Skew)와 두께가 반경 방향으로 변 화하는 복잡한 형상을 가지므로 단순보나 판 요소로 모델링하 는 것은 충분한 신뢰성을 요구하는 상황에서 적합하지 않다. 본 수치해석법은 구조해석을 위해 20절점을 갖는 요소(20-nodes quadratic element)를 적용하였으며, 해당 요소는 Fig. 1에 나타난 형상을 갖는다. 이때, 각 절점의 좌표는 식 (1)과 같으며 $\underline{x}_{i}$ 는 $i$ -번째 절점의 좌표, $(\xi, \eta, \zeta)$ 는 요소의 국부 좌표, $N_{i}$ 는 요소의 형상 함수를 나타낸다. 또한 변형률 $(\underline{\epsilon})$ 과 변형량 $(d)$ 의 관계는 식 (2)로 정의된다.

$$
\underline{x}(\xi, \eta, \zeta)=\sum_{i=0}^{19} N_{i}(\xi, \eta, \zeta) \underline{x}_{i}
$$

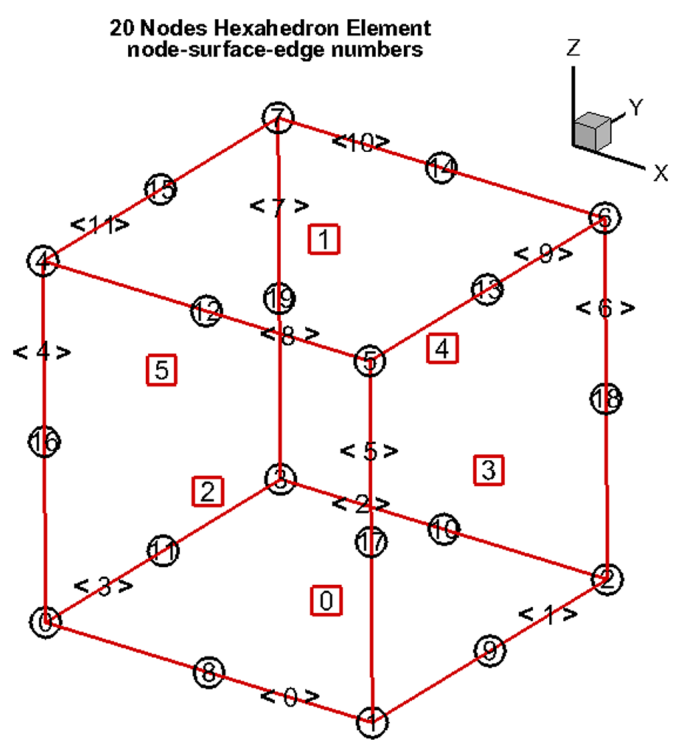

Fig. 1 Coordinate system of $3 \mathrm{~d} 20$-nodes quadratic element

$\{\underline{\epsilon}\}=[B]\{d\}$

이때, $[B]=\left[\begin{array}{ccc}\partial N_{i} / \partial x & 0 & 0 \\ 0 & \partial N_{i} / \partial y & 0 \\ 0 & 0 & \partial N_{i} / \partial z \\ \partial N_{i} / \partial y & \partial N_{i} / \partial x & 0 \\ 0 & \partial N_{i} / \partial z & \partial N_{i} / \partial y \\ \partial N_{i} / \partial z & 0 & \partial N_{i} / \partial x\end{array}\right]$

훅의 법칙(Hooke's law)에 따라 응력( $\sigma)$ 은 다음 식 (3)으로 정의 되며, $E_{i}, G_{i j}, \nu_{i j}$ 는 각각 영률 또는 탄성 계수(Young's modulus), 전단 탄성 계수(Shear modulus), 푸아송 비(Poisson's ratio)이다.

$$
\{\underline{\sigma}\}=[D]\{\underline{\epsilon}\}=[D][B]\{d\}
$$

여기서 요소가 직교 선형 탄성 재료로 구성된다고 가정하면 컴플 라이언스 행렬(Compliance matrix, $C$ )과 강성 행렬(Stiffness matrix, $D$ )은 아래와 같이 정의되며, 계수 $d_{i j}$ 는 식 (6)-(8)과 같다.

$$
C=\left[\begin{array}{cccccc}
1 / E_{x} & -\nu_{x y} / E_{x}-\nu_{x z} / E_{x} & 0 & 0 & 0 \\
-\nu_{y x} / E_{y} & 1 / E_{y} & -\nu_{y x} / E_{y} & 0 & 0 & 0 \\
-\nu_{z x} / E_{z} & -\nu_{z y} / E_{z} & 1 / E_{z} & 0 & 0 & 0 \\
0 & 0 & 0 & 1 / 2 G_{y z} & 0 & 0 \\
0 & 0 & 0 & 0 & 1 / 2 G_{x z} & 0 \\
0 & 0 & 0 & 0 & 0 & 1 / 2 G_{x y}
\end{array}\right]
$$

$$
D=\left[\begin{array}{cccccc}
d_{x x} & d_{x y} & d_{x z} & 0 & 0 & 0 \\
d_{y x} & d_{y y} & d_{y z} & 0 & 0 & 0 \\
d_{z x} & d_{z y} & d_{z z} & 0 & 0 & 0 \\
0 & 0 & 0 & 2 G_{y z} & 0 & 0 \\
0 & 0 & 0 & 0 & 2 G_{x z} & 0 \\
0 & 0 & 0 & 0 & 0 & 2 G_{x y}
\end{array}\right]
$$

$d_{x x}=\frac{1-\nu_{y z} \nu_{z y}}{E_{y} E_{z} \triangle}, d_{x y}=\frac{\nu_{y z}+\nu_{z x} \nu_{y z}}{E_{y} E_{z} \triangle}, d_{x z}=\frac{\nu_{z x}+\nu_{y x} \nu_{z y}}{E_{y} E_{z} \triangle}$ 
$d_{y x}=\frac{\nu_{x y}+\nu_{x z} \nu_{z y}}{E_{z} E_{x} \Delta}, d_{y y}=\frac{1-\nu_{z x} \nu_{x z}}{E_{z} E_{x} \Delta}, d_{y z}=\frac{\nu_{z y}+\nu_{z x} \nu_{x y}}{E_{z} E_{x} \Delta}$

$d_{z x}=\frac{\nu_{x z}+\nu_{x y} \nu_{y z}}{E_{x} E_{y} \Delta}, d_{z y}=\frac{\nu_{y z}+\nu_{x z} \nu_{y x}}{E_{x} E_{y} \Delta}, d_{z z}=\frac{1-\nu_{x y} \nu_{y x}}{E_{x} E_{y} \Delta}$

여기서, $\triangle=\frac{1-\nu_{x y} \nu_{y x}-\nu_{y z} \nu_{z y}-\nu_{z x} \nu_{x z}-2 \nu_{x y} \nu_{y z} \nu_{z x}}{E_{x} E_{y} E_{z}}$

또한, 대칭 조건으로 아래 식 (9)의 조건이 만족되며 9개의 독 립적인 물성치만 존재하기 때문에, 직교이방성 소재는 다루기 쉽고 해석에 용이한 장점을 갖는다.

$$
\nu_{x y} E_{y}=\nu_{y x} E_{x}, \nu_{y z} E_{z}=\nu_{z y} E_{y}, \nu_{z x} E_{x}=\nu_{x z} E_{z}
$$

\section{2 적층 방식에 대한 고찰}

$\mathrm{CFRP}$ 복합소재 프로펠러는 여러 층(Layer)의 탄소 섬유로 구 성된 프리프레그(적층판, $\mathrm{Ply}$ )를 다양한 각도로 적층시켜 제작 된다. 충분한 강도를 만족하면서 원하는 변형량을 발생시키는 복합소재 프로펠러를 설계하기 위해서는 이러한 복합소재의 적 층 방식에 대한 이해가 필요하다.

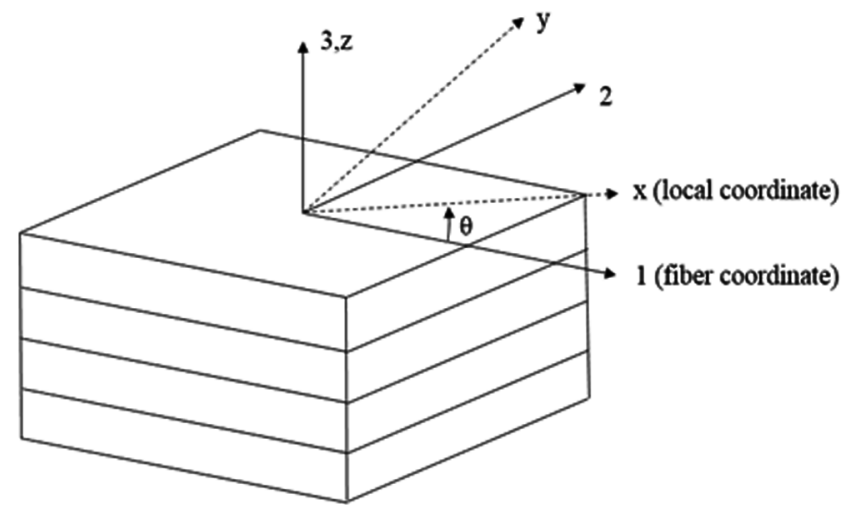

Fig. 2 Ply element in material and Cartesian coordinate systems

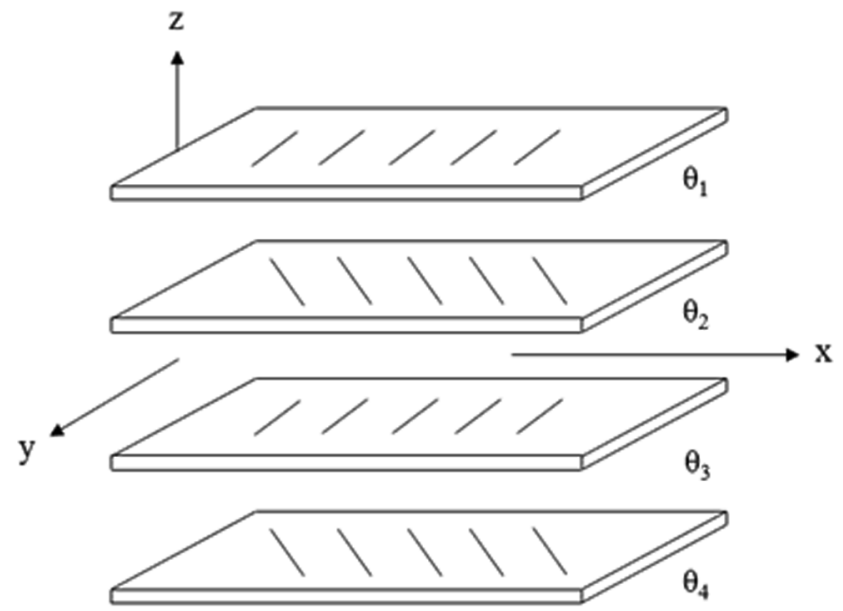

Fig. 3 An exploded view of a $\left(\theta_{1}^{\circ} / \theta_{2}^{\circ} / \theta_{3}^{\circ} / \theta_{4}^{\circ}\right)$ composite laminate
먼저 적층 각도를 정의하기 위하여 재료 좌표계(Fiber coordinate) 와 국부 좌표계(Local coordinate)를 정의한다(Fig. 2). 재료 좌표계 는 항상 1 축이 섬유 방향을 따르고 2 와 3 축이 그것과 직각을 이루 도록 한다. 재료 좌표계는 섬유(Fiber)의 방향에 따라 각 층마다 다를 수 있다(Tenek and Argyris, 1998). 또한, 다수의 층으로 구성되 는 적층판의 경우 전체 변형을 대표하는 국부 좌표가 요구되며, 본 연구에서는 전역 좌표를 국부좌표로 한다. 층에 수직 하는 3 축 을 회전축으로 하여 재료 좌표계와 국부 좌표계가 이루는 각도를 적층각(Fiber orientation angle) $\theta$ 로 정의하기로 한다. 예를 들어 다 음 Fig. 3 과 같이 서로 다른 각도를 갖는 네 개의 층으로 이루어진 적층판의 적층 방식을 $\left(\theta_{1}^{\circ} / \theta_{2}{ }^{\circ} / \theta_{3}{ }^{\circ} / \theta_{4}{ }^{\circ}\right)$ 로 표기하기로 한다. 적 층판의 강성은 이를 구성하는 층의 특성으로부터 얻을 수 있으며, 고전 적층평판 이론(Classical lamination theory, CLT)과 같은 다양 한 이론적 방법을 사용하여 개별 층의 강성으로부터 적층판의 강 성 계수를 도출할 수 있다. 적층각의 다양한 조합을 통해 특정 하중 하에서 작용하는 구조물의 변형 및 응력의 형태는 다르게 나타날 수 있으며, 더 나아가 최적의 결과를 얻을 수 있는 조합을 찾을 수 있다. 또한, 여러 각도로 적층할 경우 여러 방향의 하중에 견딜 수 있다는 장점이 있다. 다양한 적층 각도의 조합 중 실용적으로 많이 사용되는 대표적인 적층 방식은 다음과 같다.

- 대칭적 적층(Symmetric Lay-Up)

중심 면을 기준으로 서로 다른 방향으로 같은 거리에 위치한 층이 동일한 두께, 물성치, 그리고 섬유 방향을 갖는 적층 방식 을 말한다. 예를 들어 $\left(+45^{\circ} /-45^{\circ} / 0^{\circ} / 90^{\circ} / 90 \% / 0 \%-45 \%+45^{\circ}\right)$ 와 같은 적층 각도의 조합을 말하며, 이를 간략하게 $\left(+45^{\circ} /-45^{\circ} / 0^{\circ} / 90^{\circ}\right)_{\mathrm{s}}$ 로 표기한다. 반대로 비대칭 적층의 경우 $\left(+45 \%-45^{\circ} / 0^{\circ} / 90^{\circ}\right)$ $\left.+45^{\circ} /-45^{\circ} / 0^{\circ} / 90^{\circ}\right)=\left(+45^{\circ} /-45^{\circ} / 0^{\circ} / 90^{\circ}\right)_{\text {as }}$ 와 같lamination이 표기하 기로 한다. 여기서 하첨자 $s$ 는 대칭(symmetry)을, $a s$ 는 비대칭 (asymmetry)을 나타낸다.

- 등방향 혹은 $0^{\circ} / 90^{\circ}$ 적층(Unidirectional or $\left.0^{\circ} / 90^{\circ} \mathrm{Lay}-\mathrm{Up}\right)$ $\left(0^{\circ} / 0^{\circ} / 0^{\circ} / 0^{\circ}\right)$ 또는 $\left(90^{\circ} / 90^{\circ} / 90^{\circ} / 90^{\circ}\right)$, 그리고 $\left(0^{\circ} / 90^{\circ} / 0^{\circ} / 90^{\circ}\right)$ 또는 $\left(90^{\circ} / 0^{\circ} / 90^{\circ} / 0^{\circ}\right)$ 등의 적층 각도의 조합을 말하며, 이 경우 인장 또는 압축력에 강한 장점이 있지만 반대로 전단력에 취약하다.

- 준등방성 적층(Quasi-Isotropic Lay-Up)

$0^{\circ}, 90^{\circ},+45^{\circ},-45^{\circ}$ 의 적층 각도 조합을 대칭적으로 적층하는 방식을 말하며, 예를 들어 $\left(+45^{\circ} /-45^{\circ} / 0^{\circ} / 90^{\circ}\right)_{\mathrm{s}}$ 또는 $\left(+45^{\circ} / 0^{\circ} /-45^{\circ}\right)$ $\left.90^{\circ}\right)_{\mathrm{s}}$ 등의 적층 방식을 말한다. 이 경우, 인장 또는 압축력뿐만 아니라 전단력에도 강하게 작용하기 때문에 등방성 소재와 유 사한 구조적 거동 특성을 보인다.

결론적으로, 복합소재 프로펠러의 적층은 인장력과 압축력에 충분한 강도를 갖기 위하여 $0^{\circ}$ 와 $90^{\circ}$ 의 각도를 포함하면서, 원 하는 크기와 방향으로 충분한 변형이 발생하면서 프로펠러의 효율을 높일 수 있는 최적 각도 조합으로 구성되어져야 한다.

\section{3 적층 복합소재 구조해석법의 검증}

적층 복합재료의 구조 해석을 위해 앞서 등방성 소재에 대해 정립된 기존의 구조 해석 모듈인 ProSTEC을 대신하여 직교이방 성 소재와 적층 모델을 지원하는 FEM solver인 OOFEM(Object 


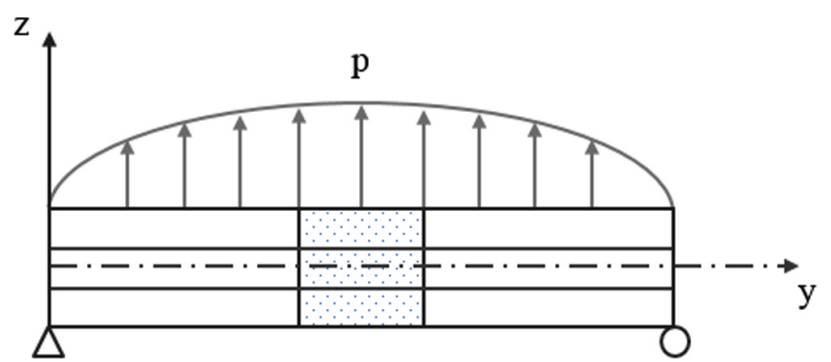

Fig. 4 Simply supported composite plate under cylindrical bending

oriented finite element solver)을 구조 해석 모듈로 적용하였다 (Patzak, 2012). 새롭게 적용한 구조 해석 모듈의 검증을 위해 길 이 $L=10 \mathrm{~m}$, 높이 $H=2.5 \mathrm{~m}$, 폭 $B=1.0 \mathrm{~m}$ 인 단순지지된 적층판의 구 조 해석을 수행하였다(Fig. 4). 이때, 적층판은 $y-z$ 평면에 대한 거동만 허용되며, $y=0$ 인 위치에서 핀지지 조건으로 $D_{y}$ 와 $D_{z}$ 자 유도를, $y=L$ 인 위치에서 롤러 지지조건으로 $D_{z}$ 자유도만을 구 속한다.

적층판은 직각으로 교체된 3 개의 판 $\left(3-\mathrm{ply}, 0^{\circ} / 90^{\circ} / 0^{\circ}\right)$ 으로 구 성되어 있으며, $p=\sin (\pi x / L)$ 의 원통형 굽힘 하중을 받는다. 또 한, 계산된 적층판의 물성치를 다음 Table 1과 같다.

계산을 위해 2.1 에서 언급한 20절점의 3 차원 요소를 사용하였 으며, $x, y$ 방향으로 4개, $z$ 방향(두께 방향)으로 6 개를 적용하 여 전체 요소의 개수는 96 개, 절점의 개수는 605 개이다. 1 개의 판은 두께 방향으로 2 개의 요소로 구성하였으며, 각 요소는 두 께 방향으로 3 개의 층으로 모델링 되어 있다. 각 층의 재질을 포함하는 물성치의 연속성은 Gauss 보간법을 통해 보장된다. Fig. 5와 6은 각각 중심 면 $(y=L / 2)$ 에 작용하는 수직 응력 $\left(\sigma_{y y}\right.$

Table 1 Material Property of simply supported composite plate

\begin{tabular}{cccccc}
\hline \hline$E_{1}$ & $172.4 \mathrm{GPa}$ & $G_{12}$ & $3.45 \mathrm{GPa}$ & $\nu_{12}$ & \\
$E_{2}$ & & $G_{13}$ & & $\nu_{13}$ & 0.34 \\
$E_{3}$ & $6.9 \mathrm{GPa}$ & $G_{23}$ & $1.38 \mathrm{GPa}$ & $\nu_{23}$ & \\
\hline
\end{tabular}

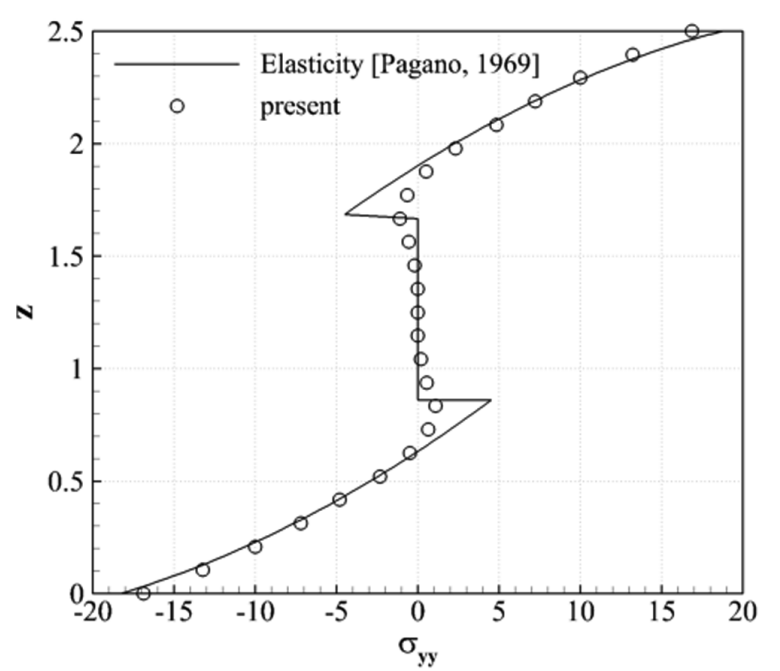

Fig. 5 Axial stress $\left(\sigma_{y y}\right)$ distribution at the mid-span of the simply supported composite plate

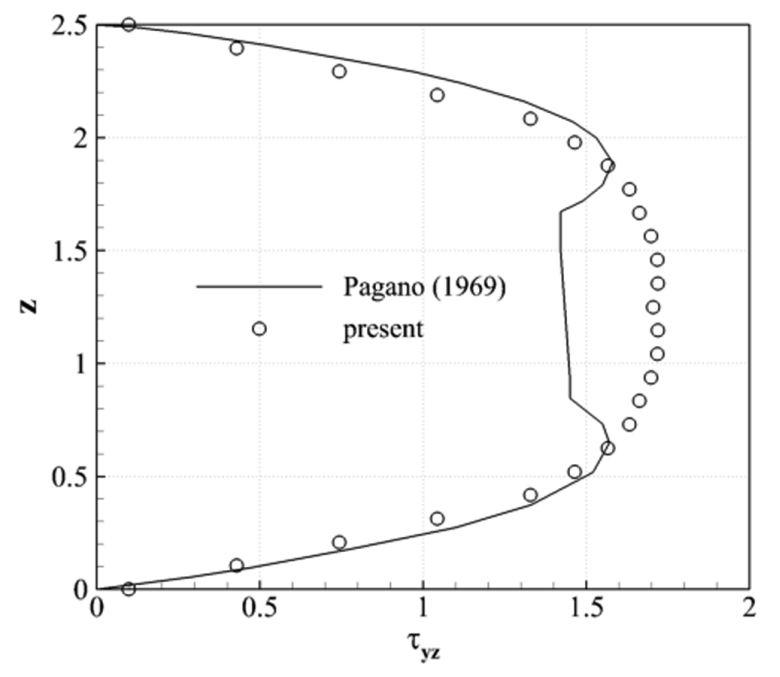

Fig. 6 Transverse shear $\operatorname{stress}\left(\tau_{y z}\right)$ distribution at supports of the simply supported composite plate

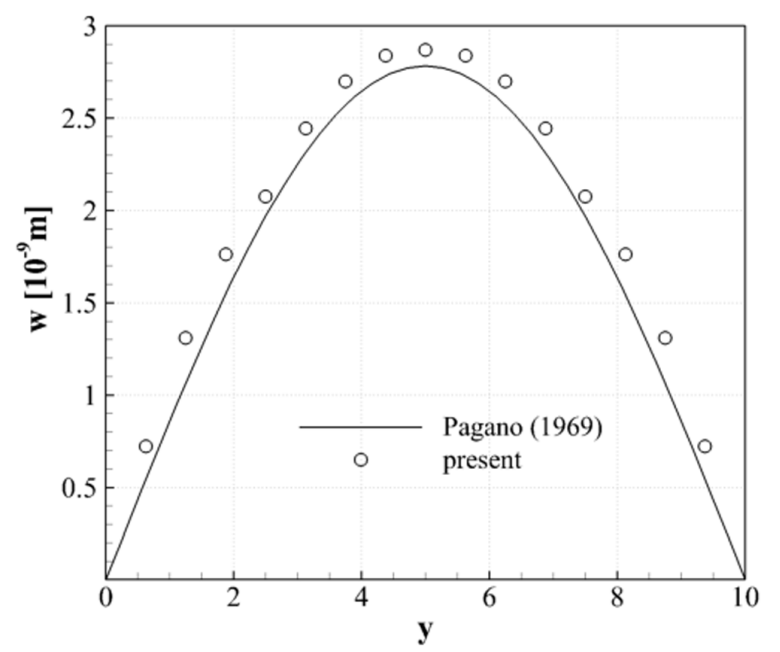

Fig. 7 Vertical deflection $(w)$ distribution at the mid-span of the simply supported composite plate

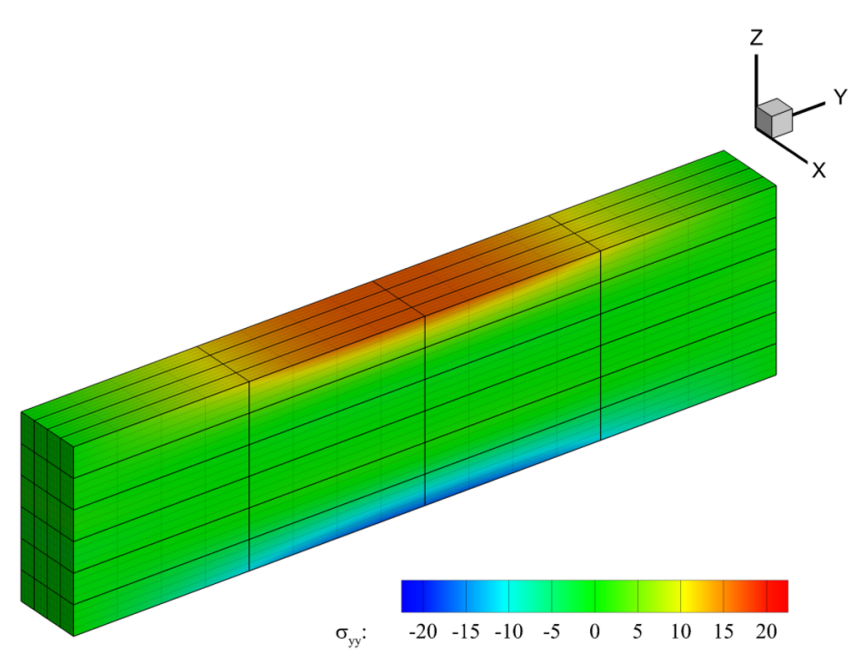

Fig. 8 Axial stress distribution of the simply supported composite plate 


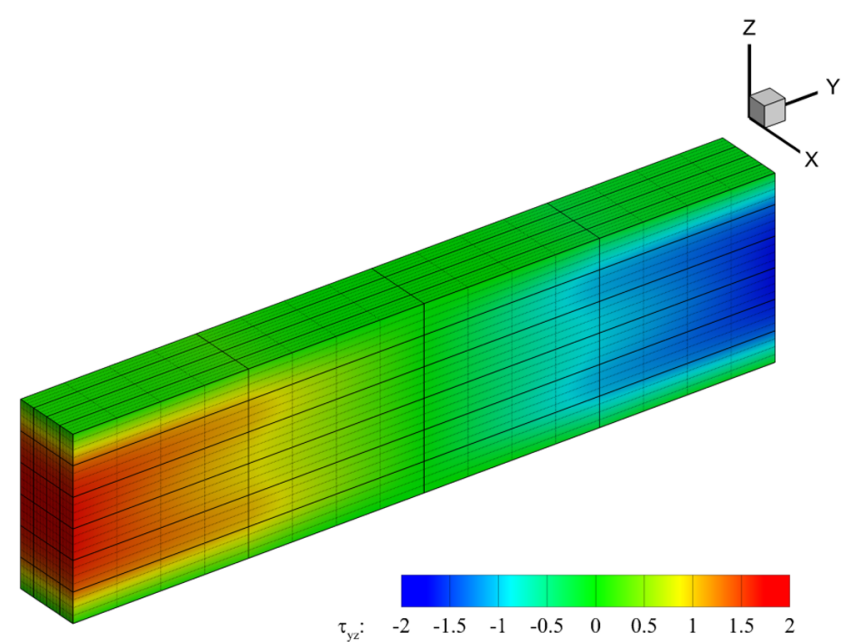

Fig. 9 Transverse shear stress distribution of the simply supported composite plate

$[\mathrm{Pa}])$ 과 지지부 $(y=0)$ 에 작용하는 전단 응력 $\left(\tau_{y z}[\mathrm{~Pa}]\right)$ 을 Pagano (1969)의 해석해와 비교하여 나타낸 결과이며, 응력 분포의 경 향과 그 값이 잘 일치하는 것을 확인할 수 있다. 전단 응력의 경우 $90^{\circ}$ 의 각도로 적층된 중간판의 위치에서 결과 값이 다소 다르게 나타나고 있지만, Pagano(1969)의 해석해의 경우 세 개 의 판을 분리하여 해석을 수행하였기 때문에 발생하는 차이로 판단된다. 또한 $z$ 방향 변형량 $(w)$ 을 비교한 결과(Fig. 7), 본 수 치해석 결과와 해석해가 잘 일치함을 확인하였다.

또한, Figs. 8-9는 각각 수치해석을 통해 계산된 전체 적층판 에 작용하는 수직 응력과 전단 응력의 분포를 보여준다.

\section{3. 적층 복합소재 프로펠러의 유체-구조 연성해석}

복합소재 프로펠러의 유체-구조 연성해석을 수행하기 위해 개발 된 프로그램인 ProFem의 해석 절차를 Fig. 10에 도식적으로 나타내었 다. 본 단계에서는 적층 복합소재 프로펠러의 유체-구조 연성해석 방법의 정립을 목표로 1-way coupling method로 계산을 수행하였다.

새롭게 정립한 수치해석법의 검증을 위하여 이전 연구단계에 서 계산된 등방성 시험 모델인 KP534 프로펠러가 동일한 계산 조건인 비정상상태 불균일 유동장 내에서 작동할 때의 응력 및 변형량을 계산하여 비교하였다(Kim et al., 2018). KP534 프로펠 러는 프로펠러 날개 수 $Z=6$, 프로펠러 직경 $D=1.0 \mathrm{~m}$, 허브비 $h / D=0.18$ 으로 등방성 재질(NAB, Nickel-Aluminum-Bronze)로 제작된 KP534의 물성치는 다음 Table 2와 같다.

KP534 프로펠러의 자세한 형상 정보를 아래 Table 3에 나타 내었다. 여기서, $r$ 은 프로펠러 중심에서 반경 방향 거리, $R$ 은 프로펠러 반경, $P$ 는 피치, $X_{G}$ 는 레이크, $\theta_{m}$ 는 스큐, $c$ 는 코드, $f_{0}$ 는 최대 캠버, $t_{0}$ 는 최대 두께를 나타낸다. Fig. 11은 유체해석 법에 사용된 이산화된 프로펠러 날개와 후류면을 보여준다. 프 로펠러가 각속도 $w$ 로 회전하고 이산회된 시간 간격이 $\Delta t$ 일 때 피치각을 갖는 후류면은 운동학적 및 동적 경계조건을 만족하 며 $w \Delta t$ 의 간격으로 날개 끝에서 발생한다. 본 해석에서 프로펠 러 날개는 코드 방향으로 21 개, 스팬방향으로 25 개의 등간격 격 자로 이루어져 있으며, 피치각을 갖는 후류면은 스팬방향으로

Table 2 Material Property of NAB

\begin{tabular}{llllll}
\hline \hline$E$ & $120.0 \mathrm{GPa}$ & $\nu$ & 0.34 & $\rho$ & $7,600 \mathrm{~kg} / \mathrm{m}^{3}$
\end{tabular}

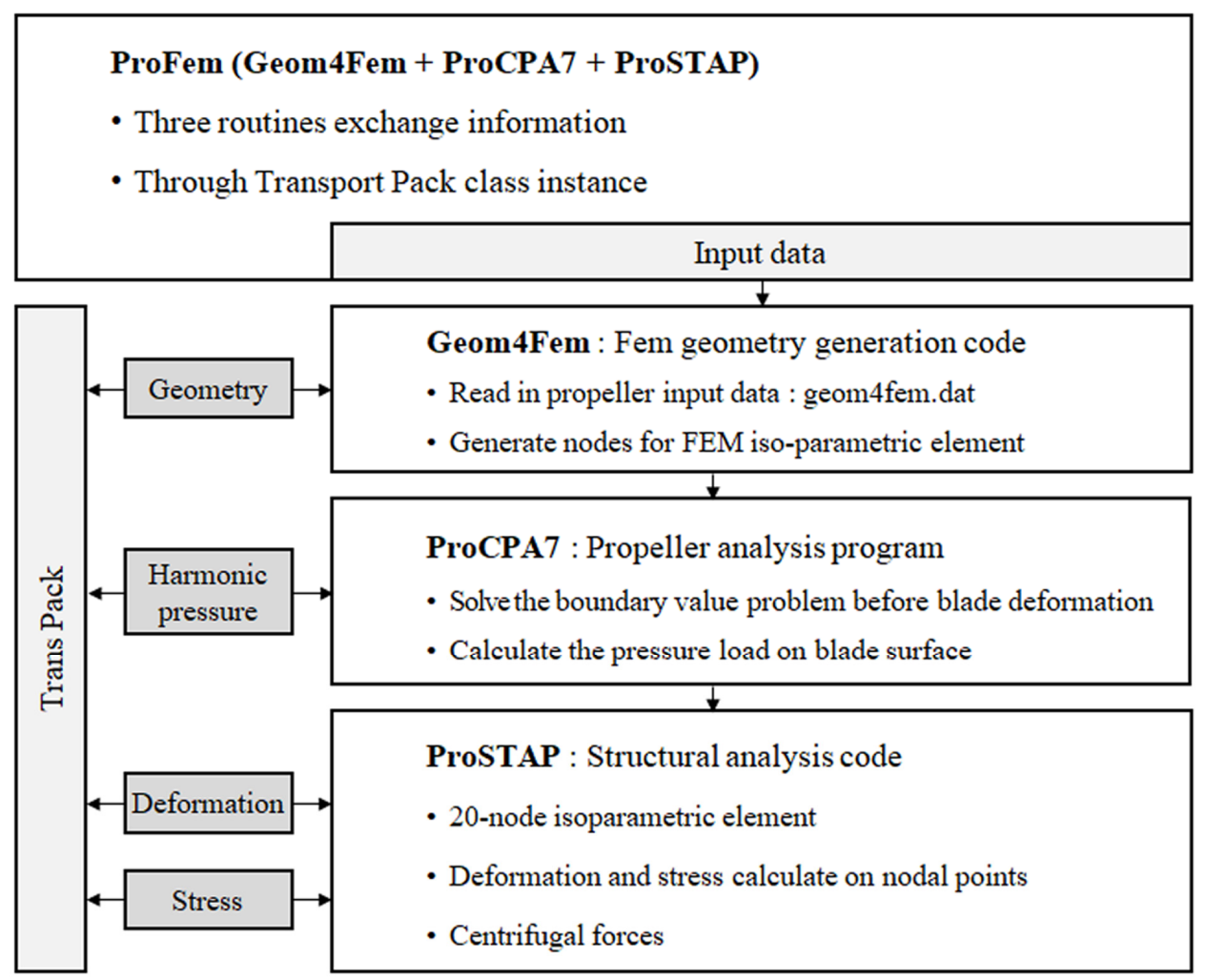

Fig. 10 Iteration procedure for the prediction of behavior of propeller blade 
Table 3 Geometry of KP534 propeller

\begin{tabular}{cccccccc}
\hline \hline$r / R$ & $P[\mathrm{~mm}]$ & $X_{G}[\mathrm{~mm}]$ & $\theta_{m}[\mathrm{deg}]$ & $c[\mathrm{~mm}]$ & $f_{0}[\mathrm{~mm}]$ & $t_{0}[\mathrm{~mm}]$ \\
\hline 0.18 & 834.7 & 0 & -4.72 & 168.7 & 5.04 & 45.85 \\
0.25 & 891.2 & 0 & -6.98 & 190.9 & 5.94 & 40.71 \\
0.30 & 926.9 & 0 & -7.82 & 204.8 & 6.33 & 37.12 \\
0.40 & 978.3 & 0 & -7.74 & 228.8 & 6.43 & 30.47 \\
0.50 & 1007.9 & 0 & -5.56 & 248.2 & 5.73 & 24.59 \\
0.60 & 1013.0 & 0 & -1.50 & 260.5 & 4.74 & 19.47 \\
0.70 & 996.7 & 0 & 4.11 & 261.7 & 3.86 & 14.92 \\
0.80 & 956.6 & 0 & 10.48 & 246.2 & 3.10 & 10.73 \\
0.90 & 900.6 & 0 & 17.17 & 203.9 & 2.24 & 6.93 \\
0.95 & 868.3 & 0 & 20.63 & 162.2 & 1.72 & 5.28 \\
1.00 & 833.1 & 0 & 24.18 & 0.1 & 0.67 & 3.69 \\
\hline
\end{tabular}

25 개, 회전방향으로 총 122 개의 격자로 구성되었다.

Fig. 12 와 13은 구조 해석 모듈로 ProSTEC을 사용한 결과와 $\mathrm{OOFEM}$ 을 적용하여 새롭게 계산한 결과를 비교하였다. 여기서 ProSTEC은 이전 연구 단계에서 등방성 소재에 대한 구조해석 을 위해 사용한 구조 해석 모듈이다(Jang et al., 2012; Kim et al., 2018). 해당 계산 조건은 프로펠러의 운항 조건이 회전수 $585 \mathrm{rpm}$, 전진비 $J=0.8$ 인 경우 특정 비정상 반류 조건하에서 수 행된 계산으로, 등가 응력과 변형량이 최대값을 갖는 회전 각도 $6^{\circ}$ 의 결과를 비교하였다. 흡입면에 작용하는 등가 응력과 변형 량의 분포를 살펴본 결과, 두 해석 방법을 사용한 계산 결과가 잘 일치함을 확인할 수 있다. 기존 등방성 소재에 대해 정립한 수치해석법에서는 프로펠러의 두께 방향으로 하나의 요소를 사 용하여 계산하였기 때문에, 적층 모델링을 포함하는 수정된 수 치해석법에서는 적층 판의 각도 및 개수에 대한 검증이 요구된 다. Fig. 14는 적층각이 대칭형일 경우에 기준이 되는 중심선 (Mid-surface)과 적층각 $\theta$ 의 기준선 및 방향을 나타내었다. 중심 선은 각 반경별 날개 단면의 앞날과 뒷날을 잇는 캠버선 (Camber line)으로 정의할 수 있으며, 적층각의 기준선은 날개 단면의 중점을 반경 방향으로 이은 선으로 이때, 적층각은 반시

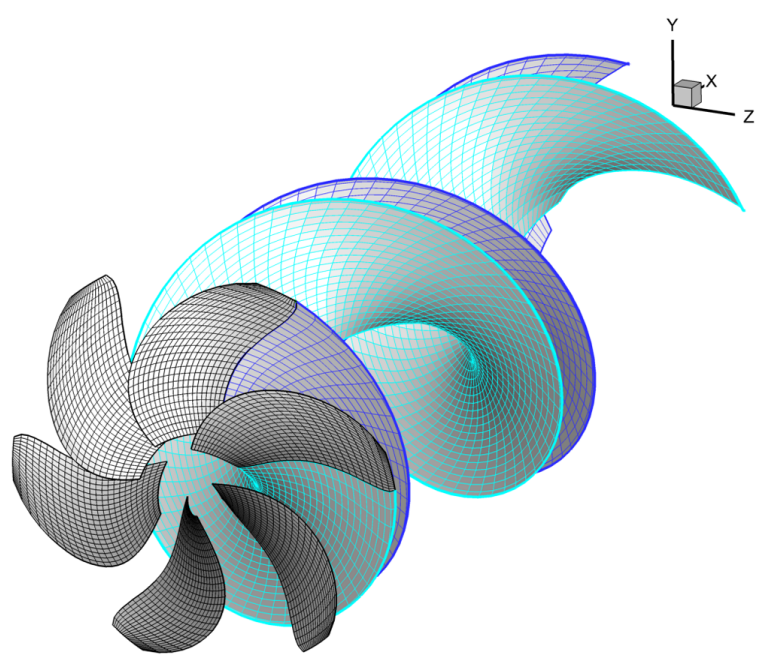

Fig. 11 Discretized propeller blades and trailing wake

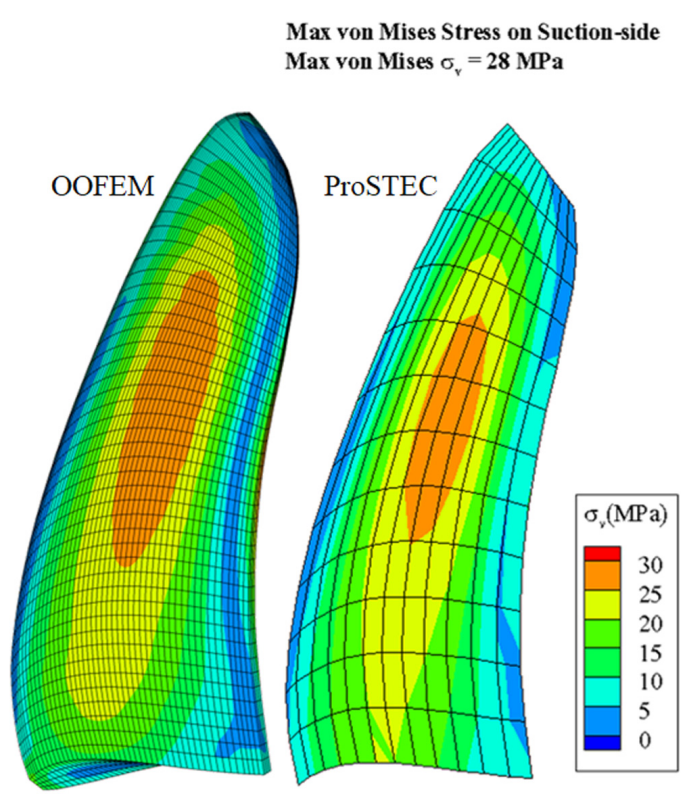

Fig. 12 Comparison of von Mises stress distribution acting on the suction side of KP534 (585 rpm, $\left.J=0.8, \theta=6^{\circ}\right)$

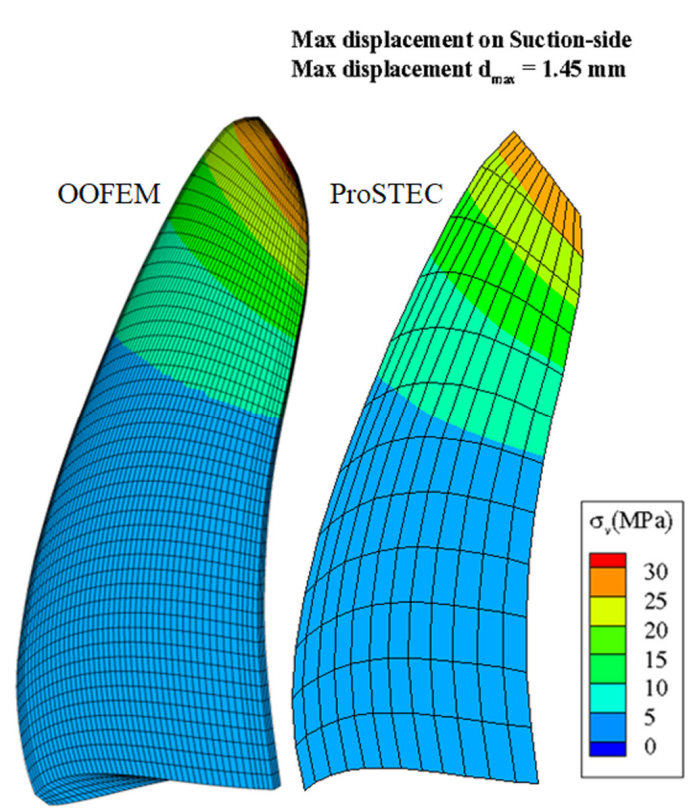

Fig. 13 Comparison of displacement distribution acting on the suction side of KP534 (585 rpm, $\left.J=0.8, \theta=6^{\circ}\right)$

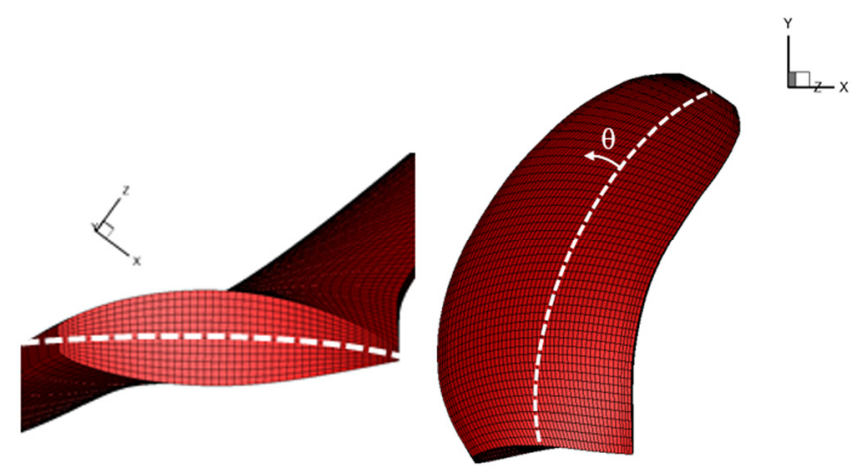

Fig. 14 Definition of the mid-surface and the fiber orientation angle 
Table 4 Material Property of Hexcel IM7-8552

\begin{tabular}{llllllll}
\hline \hline$E_{1}$ & $171.4 \mathrm{GPa}$ & $G_{12}$ & $5.29 \mathrm{GPa}$ & $\nu_{12}$ & & & \\
$E_{2}$ & & $G_{13}$ & & $\nu_{13}$ & 0.32 & $\rho$ & $1,500 \mathrm{~kg} / \mathrm{m}^{3}$ \\
$E_{3}$ & $9.08 \mathrm{GPa}$ & $G_{23}$ & $2.00 \mathrm{GPa}$ & $\nu_{23}$ & & & \\
\hline
\end{tabular}

계 방향을 양 $(+)$ 의 값으로 한다.

적층 판의 개수에 따른 프로펠러의 응력 및 변형량의 차이를 살펴보기 위하여 시험 모델인 $\mathrm{KP} 534$ 프로펠러가 $J=0.6$ 인 $(n=$ 585.5) 조건으로 균일 유동장 내에서 작동할 때, 해석을 위해 사 용된 직교이방성 CFRP 복합소재(Hexcel IM7-8552)의 물성치는 다음과 Table 4와 같다(Camanho and Lambert, 2006).

이때 복합소재 프로펠러의 두께 방향 요소의 개수, 즉 적층 판의 개수를 1 4개까지 증가시키며 프로펠러에 작용하는 등가 응력 분포(Fig. 15)와 변형량(Fig. 16)을 살펴보았다.

여기서, 적층 판은 각각 5 개의 층으로 이루어져 있으며, 적층
각도는 $90^{\circ}$ 로 일정하다. 계산 결과 적층 판의 개수가 1 개인 경 우를 제외하고 그 결과 값이 크게 다르지 않음을 확인하였다. 또한, 물성치 변화에 따른 프로펠러의 응력 및 변형량의 차이를 살펴보기 위하여 KP534 프로펠러가 동일한 계산 조건에서 앞선 등방성 소재(NAB)와 직교이방성 CFRP 복합소재(Hexcel IM78552, no. of $\mathrm{Ply}=4$, no. of Layer $=5, \theta=90^{\circ}$ )로 이루어진 경우 그 해석 결과를 비교하였다. Fig. 17은 각각 등방성과 직교이방성 소재의 프로펠러 날개의 흡입면과 압력면에 작용하는 등가응력 (von Mises stress)의 분포를 나타내며, Fig. 18은 두 가지 프로펠 러 끝단의 변형 전(회색)과 변형 후(붉은색)의 형상을 비교한 결 과이다. 등가 응력 분포는 크게 차이를 보이지 않고 있지만, 물 성치의 변화만으로도 복합소재 프로펠러의 변형량이 크게 차이 를 보임을 확인할 수 있다. 또한, 앞서 언급하였듯이 $0^{\circ}, 90^{\circ}$, $+45^{\circ},-45^{\circ}$ 의 조합으로 적층을 할 경우, Fig. 19와 Fig. 20에서 나 타난 등가응력과 변형량 분포를 통해 확인할 수 있듯이, 복합소 재 프로펠러의 거동이 등방성 소재와 유사함을 알 수 있다.
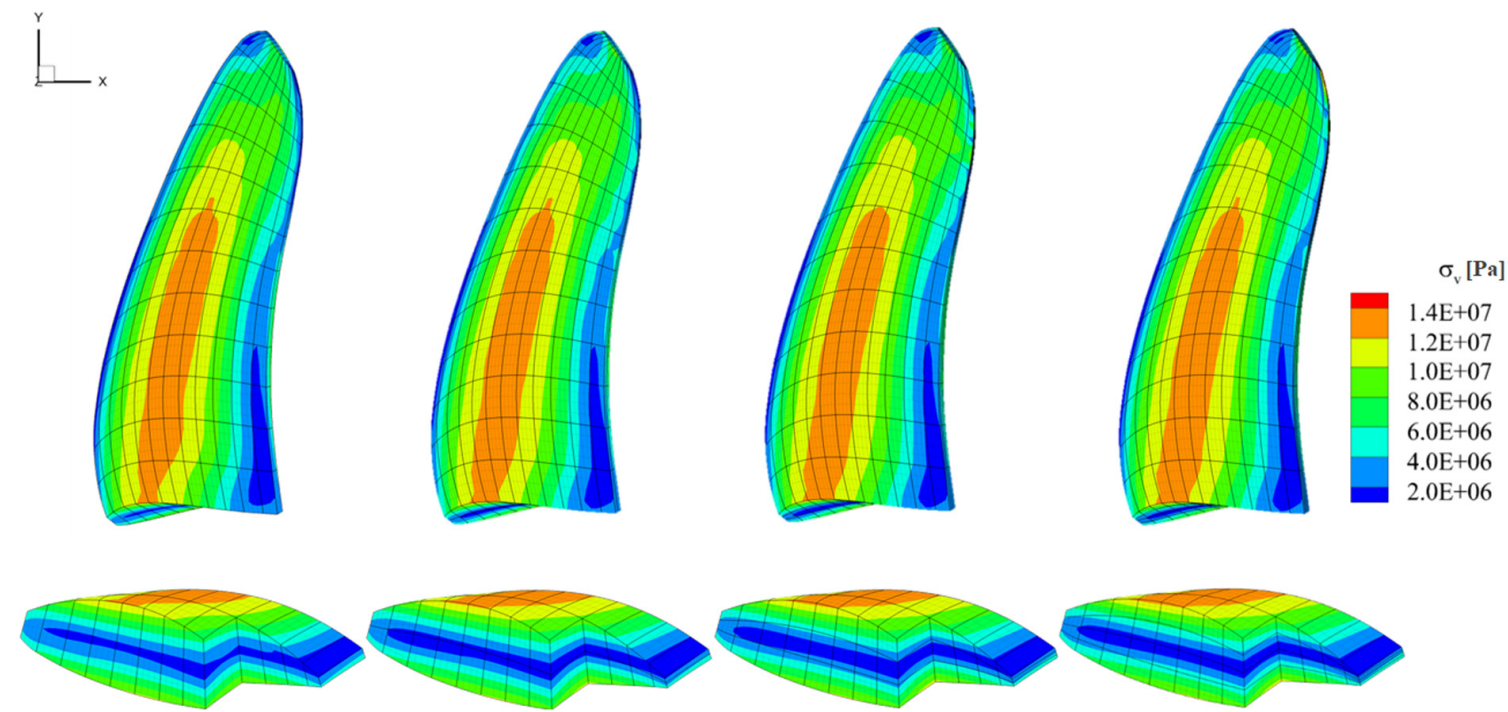

Fig. 15 Comparison of von Mises stress distribution of KP534 according to the number of ply

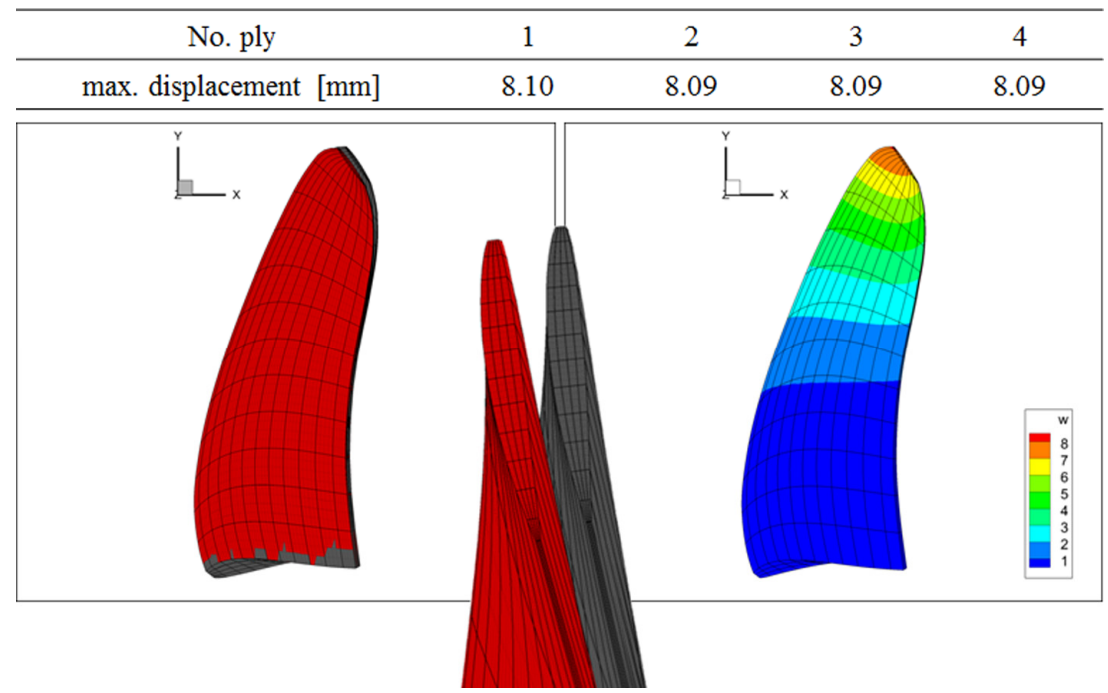

Fig. 16 Comparison of the max. displacement of KP534 according to the number of ply 


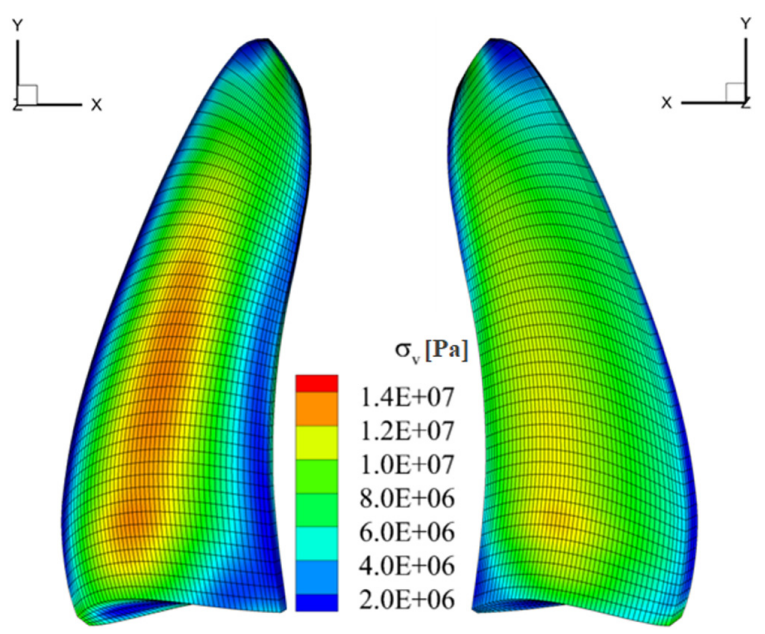

(a) Isotropic linear elastic material (NAB)

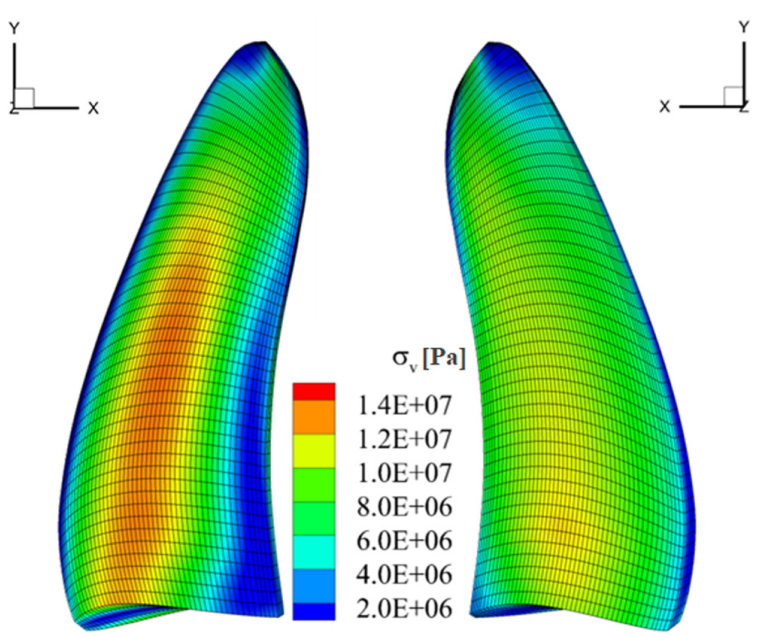

(b) Orthotropic linear elastic material (Hexcel IM7-8552)

Fig. 17 Predicted von Mises stress distributions of KP534 ( $J=0.6, n=585.5)$

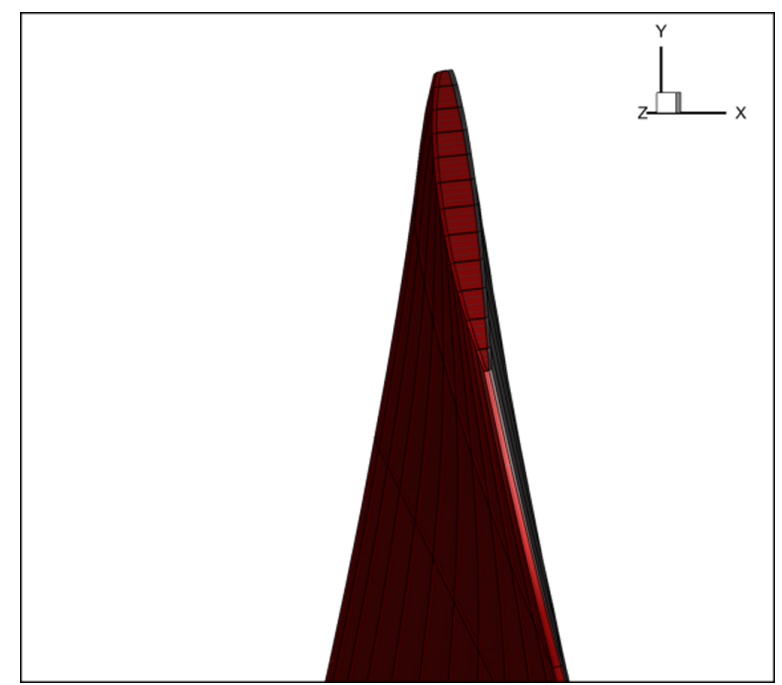

(a) Isotropic linear elastic material $(\mathrm{NAB})$

Fig. 18 Deformed geometry of KP534 $(J=0.6, n=585.5)$

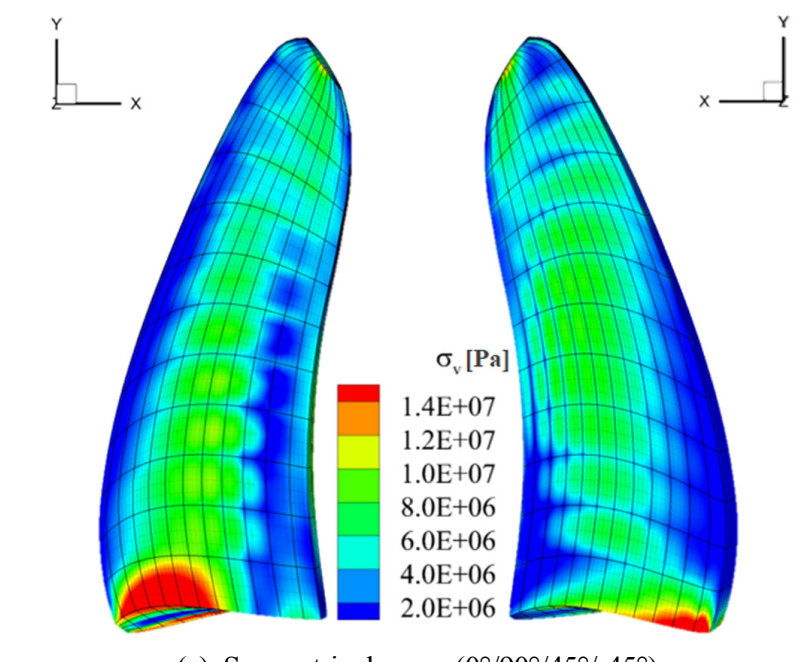

(a) Symmetric lay-up $\left(0^{\circ} / 90^{\circ} / 45^{\circ} /-45^{\circ}\right)_{\mathrm{s}}$

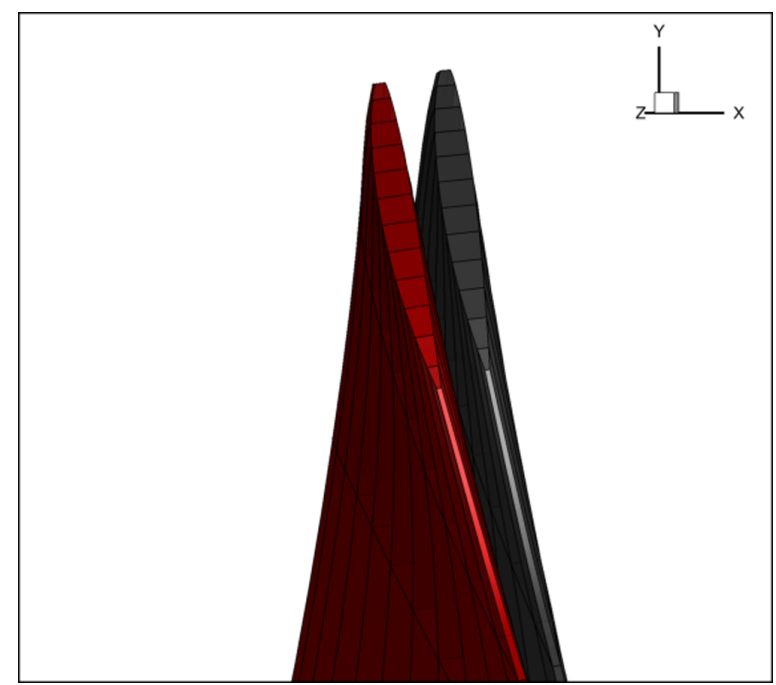

(b) Orthotropic linear elastic material (Hexcel IM7-8552)

Fig. 19 Predicted von Mises stress distributions of $\operatorname{KP534}(J=0.6, n=585.5)$

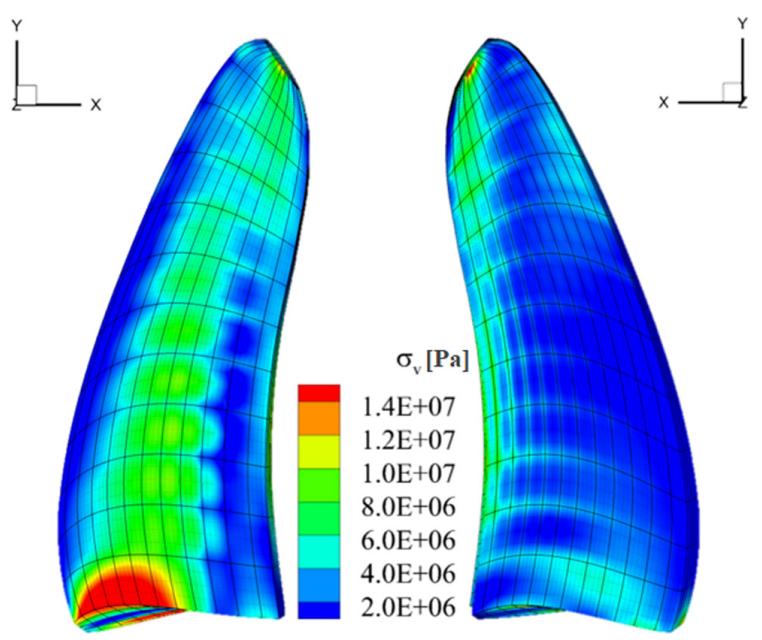

(b) Symmetric lay-up $\left(0^{\circ} / 90^{\circ} / 45^{\circ} /-45^{\circ}\right)_{\text {as }}$ 


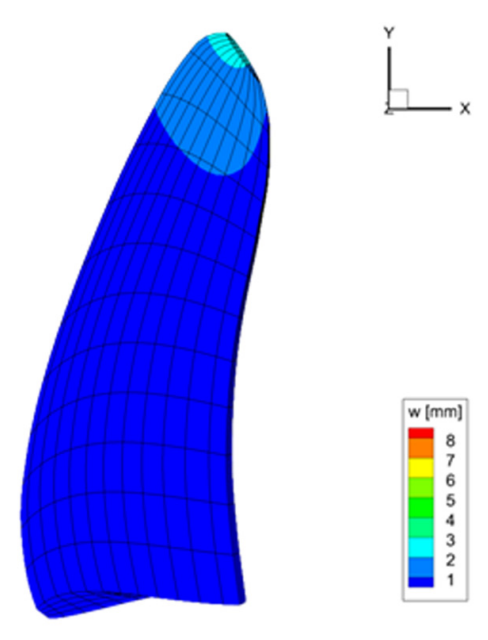

(a) symmetric lay-up $\left(0^{\circ} / 90^{\circ} / 45^{\circ} /-45^{\circ}\right)_{\mathrm{s}}$

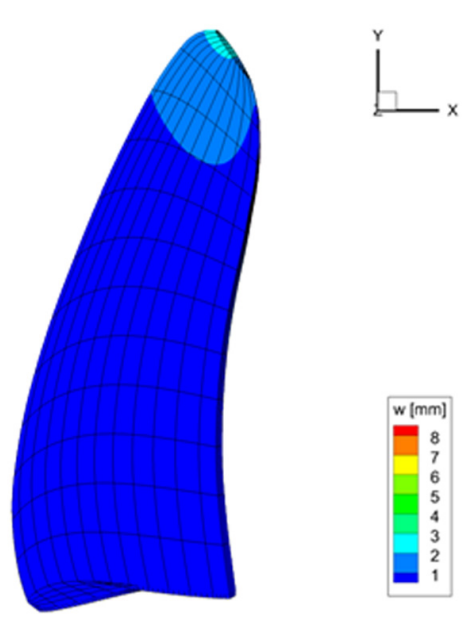

(b) Symmetric lay-up $\left(0^{\circ} / 90^{\circ} / 45^{\circ} /-45^{\circ}\right)$ as

Fig. 20 Predicted displacement distributions of $\operatorname{KP534}(J=0.6, n=585.5)$

\section{4. 결 론}

본 연구에서는 등방성 소재를 갖는 유연 프로펠러 성능 해석 에 국한하여 개발되었던 유체-구조 연성해석 프로그램을 적층 복합소재를 갖는 유연 프로펠러의 성능이 가능하도록 기존의 구조해석 방법으로 전환하였다. 수치해석법의 검증을 위하여 단순지지 적층판의 해석해와 수치해석 결과를 비교하였고, 특 정 프로펠러에 대한 수치해석을 수행하여 복합소재의 물성치 및 적층 방식이 균일 유동장 내에서 작동하는 복합소재 유연 프로펠러의 응력 및 변형량에 미치는 영향을 평가하였다. 앞선 계산 결과들로 미루어보아, 복합소재는 적층 기법에 따라 등방 성 소재와 동일한 구조 강도를 가지면서도 무게가 현저히 절감 된 프로펠러의 설계를 가능하게 한다. 또한, 구조 강도를 유지 하면서도 특정 운항 조건에서 프로펠러의 효율이 높아지는 방 향으로 변형을 발생시키는 최적 적층 설계 기법과 실질적인 제 작을 위한 가공 기법들의 연구가 병행된다면, 복합소재 프로펠 러는 차세대 선박용 프로펠러로서 충분히 연구할 가치가 있다 고 판단된다.

$$
\text { 후기 }
$$

본 연구는 산업통상자원부의 산업핵심기술개발사업(10062293) 의 지원으로 수행된 연구결과 중 일부임을 밝히며, 연구비 지원에 감사드립니다. 또한, 본 연구에 기반이 된 해석 프로그램을 제공해 주시고, 프로그램의 개발을 위해 아낌없는 조언을 해주신 이창섭 교수님께 다시 한 번 깊은 감사를 드립니다.

\section{References}

Camanho, P., Lambert, M.A., 2006. A Design Methodology for Mechanically Fastened Joints in Laminated Composite Materials. Composites Science Tehcnology, 66(15), 3004-3020. https://doi.org/10.1016/j.compscitech.2006.02.017
Chen, B., Neely, S., Michael, T., Gowing S., Szwerc, R., Buchler, D., Schult, R., 2006. Design, Fabrication and Testing of Pitch-Adapting(Flexible) Composite Propellers. Proceedings of the SNAME Propeller/Shafting Symposium, Williamsburg VA USA.

Hong, Y., He, X.D., Wang, R.G., 2012. Vibration and Damping Analysis of a Composite Blade. Materials and Design, 34, 98-105. https://doi.org/10.1016/j.matdes.2011.07.033

Hong, Y., Wilson, P.A., He, X.D., Wang, R.G., 2017. Numerical Analysis and Performance Comparison of the Same Series of Composite Propellers. Ocean Engineering, 144(1), 211-223. https://doi.org/10.1016/j.oceaneng.2017.08.036

Jang, H.G., Nho, I.S., Hong, C.H., Lee, C.S., 2012. Design Algorithms of Flexible Propeller by Fluid-Structure Interactive Analysis. Journal of the Society of Naval Architects of Korea, 49(6), 528-533. https://doi.org/10.3744/SNAK.2012.49.6.528

Kim, J.H., Ahn, B.K., Kim, G.D., Lee, C.S., 2018. Numerical Prediction of Hydroelastic Performance of the Flexible Composite Propeller. Proceedings of the $28^{\text {th }}$ International Ocean and Polar Engineering Conference, Sapporo Japan.

Lee, H., Song, M.C., Han, S., Chang, B.J., Suh, J.C., 2017. Hydro-elastic Aspects of a Composite Marine Propeller in Accordance with Ply Lamination Methods. Journal of Marine Science and Technology, 22(3), 479-493. https://doi.org/ 10.1007/s00773-016-0428-4

Lin, G.F., 1991. Comparative Stress/Deflection Analysis of a Thick-Shell Composite Propeller Blade. David Taylor Research Center Technical Report, DTRC/SHD-1373-01.

Lin, H.J., Lin, J.J., 1996. Nonlinear Hydroelastic Behavior of Propellers Using a Finite Element Method and Lifting Surface Theory. Journal of Marine Science and Technology, 1(2), 114-124. https://doi.org/10.1007/BF02391167

Lin, H.J., Lin, J.J., Chuang, T.J., 2005. Strength Evaluation of a Composite Marine Propeller Blade. Journal of Reinforced 
Plastics and Composites, 24(17), 1791-1807. https://oi.org/ 10.1177/0731684405052199.

Motley, M.R., Liu, Z., Young, Y.L., 2009. Utilizing Fluid-structure Interactions to Improve Energy Efficiency of Composite Marine Propellers in Spatially Varying Wake. Composite Structures, 90(3), 304-313. https://doi.org/10.1016/j.compstruct.2009.03.011.

Motley, M.R., Young, Y.L., 2011. Performance-based Design and Analysis of Flexible Composite Propulsors. Journal of Fluids and Structures, 27, 1310-1325. https://doi.org/10.1016/ j.jfluidstructs.2011.08.004

Motley, M.R., Kramer, M.R., Young, Y.L., 2013. Free Surface and Solid Boundary Effects on the Free Vibration of Cantilevered Composite Plates. Composite Structures, 96, 365-375. https:// doi.org/10.1016/j.compstruct.2012.09.023

Mouritz, A.P., Gellert, E., Burchill, P., Challis, K., 2001. Review of Advanced Composite Structures for Naval Ships and
Submarines. Composite Structure, 53(1), 21-41. https://doi.org/ 10.1016/S0263-8223(00)00175-6

Nho, I.S., Lee, J.Y., Lee, H.Y., Lee, C.S., 2004. A Dynamic Structural Analysis System for Propeller Blades. Journal of the Society of Naval Architects of Korea, 41(2), 114-120.

Pagano, N., 1969. Exact Solution for Composite Laminates in Cylindrical Bending. Journal of Composite Materials, 3(3), 398-411.

Patzak, B., 2012. OOFEM - An Object-oriented Simulation Tool for Advanced Modeling of Materials and Structures. Acta Polytechnica, 52(6), 59-66.

Tenek, L.T., Argyris, J., 1998. Finite Element Analysis for Composite Structure. Kluwer Academic Publishers.

Young, Y.L., 2008. Fluid-structure Interaction Analysis of Flexible Composite Marine Propellers. Journal of Fluids and Structures, 24(6), 799-818. https://doi.org/10.1016/j.jfluidstructs.2007.12.010. 